\title{
Antecedentes veterotestamentários da Eucaristia Aspectos culturais e religiosos
}

\author{
Old Testament background of the Eucharist \\ Religious and cultural aspects
}

\author{
Boris Agustín Nef Ulloa \\ Regina Ribeiro Graciani
}

\section{Resumo}

A proposta desta pesquisa é expressar elementos da Eucaristia que refletem traços precisos do Antigo Testamento. As antigas práticas judaicas explicitadas no Antigo Testamento apresentam a refeição e seu sentido sagrado. A refeição se eleva à esfera religiosa, de modo especial na ceia da Páscoa, que é para os judeus um sinal e celebração da salvação operada por Deus em favor deles. Converteu-se em ponto de referência para toda a sua teologia e espiritualidade. Assim, o Antigo Testamento, a cultura judaica e também a de outros povos vizinhos fornecem chaves para melhor compreender o mistério cristão da Eucaristia. Jesus e a comunidade primitiva são devedores da liturgia judaica. Guiados por ela, apontaremos as preliminares da Eucaristia, seus sinais precursores.

Palavras-chave: refeição; Páscoa; relação AT-NT; Ceia pascal.

\section{Abstract}

The aim of this article is to state elements of the Eucharist which reflect precise traces in the Old Testament. The ancient Jewish practices explained in the Old Testament present the meal and its sacred sense. The meal rises to 
the religious sphere, especially at supper Easter, which is to the Jews a sign and celebration of the salvation brought by God in their behalf. He became a reference point to all of his theology and spirituality. Thus, the Old Testament, Jewish culture as well as the culture of other neighboring people provide keys to better understand the Christian mystery of the Eucharist. Jesus and the early community are borrowers from the Jewish liturgy. Thus, the precursor signs will be pointed out here, guided by the preliminaries of the Eucharist.

Keywords: meal; supper; Easter; paschal supper.

\section{Introdução}

A oração judaica, em sua estrutura cotidiana e festiva, apresenta pontos de partida para uma fonte litúrgica comum com o cristianismo. ${ }^{1}$ Jesus de Nazaré e a comunidade primitiva são dependentes da liturgia judaica. É no Antigo Testamento que se encontram as preliminares da eucaristia, seus sinais precursores. $^{2}$

A metodologia utilizada partiu da análise de livros, artigos de revistas, de textos e documentos do Magistério da Igreja convergindo para o tema central. Para proceder ao estudo, o caminho escolhido foi partir das antigas práticas judaicas explicitadas no Antigo Testamento, que apresentam a refeição e seu sentido sagrado.

Inicialmente, a pesquisa se concentrará nas significações do alimento para a vida humana e em suas implicações antropológicas. A refeição é vista em sua dimensão comunitária e religiosa. Da reunião à mesa chega-se à celebração de festas. A reunião em comum passa a acontecer sob o olhar de Deus quando orações são adicionadas à refeição, e dessa forma, imprime-lhe um caráter divino.

A tradição judaico-cristã vai responder ao anseio de busca pelo sentido da vida no coração humano com a apresentação de um Deus que se manifesta, permanentemente, na história de um determinado povo. O evento êxodo vai mostrar de forma indelével ao povo hebreu/judeu, por meio de fatos históricos - a saída do Egito, a peregrinação no deserto e a chegada ao Monte Sinai -, que há um propósito divino na história. O Deus que se revela é o Deus que faz uma Aliança com seu povo: o Deus de Israel.

\footnotetext{
${ }^{1}$ DI SANTE, C. Liturgia Judaica. Fontes, estrutura, orações e festas. São Paulo: Paulus, 2004, p. 7.

${ }^{2}$ BROUARD, M. Eucharistia. Enciclopédia da Eucaristia. São Paulo: Paulus, 2007, p. 47.
} 
Há séculos, o ser humano se debruça sobre a verdade divina e sobre a verdade que se inscreve numa relação dualista de antítese com a mentira. Ao longo da História, a Filosofia e a Teologia guardam nomes de importantes autores, os quais se debruçaram sobre esta questão. Santo Agostinho, ao perguntar-se sobre o que move o homem no seu íntimo, vai exclamar: "Que pode a alma desejar mais ardentemente do que a verdade"? ${ }^{3}$. Séculos depois, Bento XVI responderá:

De fato, todo homem traz dentro de si o desejo da verdade última e definitiva. Por isso, Jesus, "Caminho, Verdade e Vida" (Jo 14,6), se dirige ao coração humano que se sente peregrino e sedento, ao coração que suspira pela fonte da vida, ao coração mendigo da Verdade. Com efeito, Jesus Cristo é a Verdade feita Pessoa, que atrai a si o mundo: "Jesus é a estrela polar da liberdade humana: esta, sem ele, perde a sua orientação, porque, sem o conhecimento da verdade, a liberdade desvirtua-se, isola-se e reduz-se a estéril arbítrio". Com ele, a liberdade volta a encontrar-se a si mesma. ${ }^{4}$

No sacramento da Eucaristia Jesus mostra de modo particular a verdade do amor, a própria essência de Deus (cf. 1Jo 4,8).

É Bento XVI quem nos auxilia, novamente, ao precisar o que é adoração, amor a Deus:

segundo o grego proskynèsis, adoração significa submissão, reconhecimento de Deus como nossa verdadeira medida e, segundo o latim adoratio, contato boca a boca, beijo, e, portanto, amor: a submissão torna-se união, ela nos liberta a partir do mais profundo do nosso ser... No Cenáculo, o dia do começo da criação tornou-se o dia de sua renovação; a transformação realizada no Cenáculo tem o objetivo de fazer nascer um processo de transformações, cujo fim último é a transformação do mundo. ${ }^{5}$

Com tais palavras, o papa recorda aos cristãos o poder dinâmico da vida, que é o projeto do Senhor: agir com ele para criar um mundo novo de justiça

\footnotetext{
${ }^{3}$ SANTO AGOSTINHO. Iohannis Evangelium Tractatus, 26,5 apud BENTO XVI. Sacramentum Caritatis. São Paulo: Paulinas, 2007, p. 2.

${ }^{4}$ BENTO XVI. Sacramentum Caritatis. São Paulo: Paulinas, 2007, p. 4.

${ }^{5}$ Palavras do Papa Bento XVI durante a missa do Congresso do Dia Mundial da Juventude, em Marienfeld, Alemanha, em 2005 apud LÉON-DUFOUR, X. O Pão da Vida. Um estudo teológico sobre a Eucaristia. Petrópolis: Vozes, 2010, p. 7-8.
} 
e de amor. Dessa forma, comungar não consiste em um simples contato com Jesus de Nazaré, mas é abandonar as próprias preocupações pessoais para participar da edificação do "corpo de Cristo". É encontrar o Senhor ressuscitado, engajar-se em seu projeto de construção de um mundo novo de amor e de paz, ou, mais precisamente, deixar que o Cristo vivo aja em cada ser humano que o recebe de boa vontade. Nisto consiste o discipulado.

\section{A refeição e seu sentido antropológico e sagrado}

Uma das dimensões fundamentais e mais evidentes do ser humano é a vida. O homem é homo vivens: ele é humano enquanto é vivo, ${ }^{6}$ a vida faz parte de sua essência.?

A vida humana, porém, se distingue nitidamente da vida dos outros seres viventes: o homem possui uma vida consciente de si mesmo. Esta condição implica em níveis intelectuais, espirituais, e sociais próprios, que lhe garantem uma riqueza e variedade que lhe são inerentes. Os animais, mesmo os mais evoluídos, fazem sempre as mesmas coisas e sempre do mesmo modo. Ao contrário, o homem e a mulher têm uma possibilidade variadíssima de vida, fenômeno extraordinário que tende a transbordar sistematicamente os limites que lhe são impostos. ${ }^{8}$

O fenômeno da vida é dado certo e óbvio, é rico e complexo e seu estudo reveste-se de especial interesse para o ser humano. É da sua solução que depende todo o modo de ver as coisas no plano filosófico, ético, religioso, político, social. Conceber a vida de determinado modo vai implicar diretamente na existência humana dirigindo-a segundo regras éticas, sociais e religiosas próprias.

Há muitas imagens do ser humano criadas ao longo da História das civilizações. ${ }^{9}$ Elas, porém, são parciais: todas encontram seu limite quando se tenta reduzir o rico dinamismo da natureza humana a um único denominador comum de uma única fórmula.

Destarte todas as concepções acerca da vida humana, algo básico e fundamental é essencial para que ela se desenvolva e se mantenha: a qualificada

\footnotetext{
${ }^{6}$ MONDIN, B. O homem, quem é ele?. Elementos de Antropologia Filosófica. São Paulo: Paulus, 2008, p. 43.

${ }^{7}$ Ibidem. p. 60.

${ }^{8}$ Ibidem. p. 61.

${ }^{9}$ ZILLES, U. Antropologia Teológica. São Paulo: Paulus, 2011, p. 5.
} 
alimentação cotidiana. O alimento é a fonte de vida, de força. Possibilita a sobrevivência e impulsiona a vida. O ser humano assimila os alimentos, que são parte do cosmos, da natureza, digere-os e os converte em parte de si mesmo. ${ }^{10}$

A busca de se nutrir, renovar as energias e tomar novo impulso para a vida é essencial na condição da existência humana. Nesse sentido, pode-se afirmar que o alimento é um dom de Deus, e, portanto, direito universal.

O comer também é fonte de vida comum. ${ }^{11}$ As pessoas que compartilham a mesma mesa permanecem unidas. "Comer com os outros" tem sido sinal de solidariedade, amizade, comunicação interpessoal, de festa. É o sentido de convívio, de "beber juntos", em clima de conversa. Assim, o ato de comer se converte em algo mais do que reparar as forças e alimentar-se: é o marco mais espontâneo da acolhida e da hospitalidade humanas.

A alimentação e a comensalidade são elementos fundamentais para a humanidade. Comer compartilhando do mesmo alimento e da mesma mesa, em companhia de outras pessoas, é um dos momentos mais expressivos das relações humanas. Enquanto o alimento é força para o corpo, a comensalidade e a partilha nutrem o espírito e alimentam a necessidade que todos temos de estar juntos, expressando a alegria de conviver.

Assim sendo, a refeição à mesa carrega muito mais do que a necessidade de subsistência. Ela traz todas as dimensões que o ser humano tem de vir a ser nesse mundo, no plano pessoal ou social. ${ }^{12}$ Em cada refeição, nos reunimos em torno de uma mesa comum. É possível a partilha de vida, de histórias e de vivências humanas. É possível recontar no presente o passado de nossa história. É possível fazer memória de nossa história, de nossa herança, de nossos antepassados, atualizando no presente seus feitos e ditos passados.

A refeição é uma pequena festa cotidiana que dá alegria particular ao ser humano em todas as suas dimensões. É o momento em que à volta da mesma mesa se junta à alegria de comer e beber bem a alegria do encontro. ${ }^{13}$ É uma realidade humana cujo laço de amor tem suas origens nas primeiras refeições da criança com sua mãe. Além disso, o ser humano não come como os animais, cada um no seu canto. A amizade e o amor vêm humanizar essa realidade material.

\footnotetext{
${ }^{10}$ ALDAZÁBAL, J. A Eucaristia. Petrópolis: Vozes, 2002, p. 41.

${ }^{11}$ ALDAZÁBAL, J. A Eucaristia, p. 41.

12 SILVA, M. C. "A Espiritualidade da Mesa, da Refeição e da Festa. Uma realidade humana latente à Eucaristia”, Convergência 373 (2004), pp. 306-320.

${ }^{13}$ VANIER, J. Comunidade, lugar do perdão e da festa. São Paulo: Paulinas, 2006, p. 280.
} 
Para o oriental, a refeição tomada em comum tem um significado ainda mais profundo do que para os ocidentais. ${ }^{14}$ Ela é algo mais do que uma simples reunião de amigos: convidar alguém para a própria mesa é sinal de paz, de confiança, de fraternidade, de perdão. ${ }^{15}$ Há fatos e narrações bíblicas que bem expressam tal consideração atribuída à refeição: a aliança entre Abimelec e Isaac (Gn 26,30s), o contrato entre Labão e seu sobrinho Jacó (Gn 31,54), a anistia ao último rei de Judá, Joaquim, concedida pelo rei da Babilônia, são todas marcadas pelo comer e beber em comum.

Tal significação comunitária da refeição continuou no hebraísmo antigo, acrescentando-lhe um elemento completamente novo: a oração antes e depois da refeição. Dessa forma, a refeição em comum assumia um significado completamente novo, elevando-se da esfera profana para a religiosa e se transformando de instituição meramente social em reunião realizada sob o olhar de Deus. ${ }^{16}$

Funcionava deste modo: "quando a família se reunia para a refeição, o pai tomava o pão, levantava-o de modo que todos o pudessem ver e, em nome de todos os presentes, pronunciava sobre ele uma doxologia: "Louvor a vós, Senhor, nosso Deus, rei do mundo, que fazeis nascer o pão da terra". Os presentes faziam sua esta oração de louvor respondendo "amém"; em seguida, o pai partia o pão em pedaços e os dava a cada um dos comensais; partia um pedaço para si e o comia, dando assim aos presentes o sinal para que cada um comesse o seu pedaço. Comendo o "pão da bênção" os comensais participavam da doxologia pronunciada pelo chefe de família. Depois da refeição, se recitava a oração de agradecimento: o pai ou o seu convidado fazia, assentado, a exortação: "Louvemos o Senhor, nosso Deus, ao qual pertence tudo o que acabamos de comer"! Em seguida, com a mão direita levantava o "cálice da bênção" (1Cor 10,16) um palmo acima da mesa e, com os olhos voltados para ele, recitava a oração final. Os comensais faziam sua a oração respondendo "amém" e participavam da bênção bebendo do cálice, que era passado entre eles". ${ }^{17}$

Segundo Jeremias, não se sabe como e quando foi introduzido este piedoso costume de rezar antes e depois das refeições. Vários indícios fazem supor que ele tenha se originado entre os fariseus. ${ }^{18}$

\footnotetext{
${ }^{14}$ JEREMIAS, J. Isto é o meu corpo. São Paulo: Paulinas, 1972, p. 7.

${ }^{15}$ Ibidem, p. 8.

${ }^{16}$ JEREMIAS, J. Isto é o meu corpo, p. 9.

${ }^{17}$ Ibidem, p. 9-11.

${ }^{18}$ Ibidem, p. 11. Os documentos mais antigos provêm do ambiente dos essênios, seita judaica que se considerava comunidade de salvação, e cujo centro era Qumran, no mar Morto. Os essênios provavelmente continuavam um costume dos fariseus.
} 
A partir da vida cotidiana, "ordinária" e sua mesmice rotineira, surge um elemento de ruptura: a festa, cuja realidade possui, por princípio, um aspecto de exceção que a distingue na sucessão dos dias. ${ }^{19} \mathrm{O}$ ordinário constitui aquilo que é organizado segundo certa ordem habitual, certa sequência ordenada de fatos e ações. O momento da festa quebra tal ordem habitual com um alcance afetivo e psíquico considerável. Há um momento de libertação das tensões, como a exorcizar e acalmar angústias e temores, expressar esperanças e para que transformações sejam feitas a fim de retornar ao ordinário do cotidiano da vida com a lembrança da festa passada e a expectativa em face da festa que está por vir.

O coração humano é maior que os limites do cotidiano. Tem sede de uma felicidade que parece inacessível na terra. Tem o gosto do infinito, do universal, do eterno, de qualquer coisa que dê sentido à vida humana e ao cotidiano fastidioso. A festa é como um sinal desse além, que é o céu. É o símbolo daquilo a que a humanidade aspira: uma experiência de comunhão. ${ }^{20}$ Todas as civilizações humanas instituíram festas que perpassam o tempo. ${ }^{21}$

Há uma dimensão extraordinária na festa coletiva que pode ser denominada utópica, se "utopia" for designada pelo fato de alguém se situar, pelo menos por poucos momentos, em um lugar totalmente diferente daquele em que se encontra em sua situação comum. Há um distanciamento em relação aos códigos e ritos que regem o sistema de relações e comunicações no grupo habitual, e, assim, surge um espaço transitório de liberdade. É este o significado bastante real da festa. ${ }^{22}$ É permissível a expansão das verdadeiras aspirações pessoais e coletivas por ocasião da festa, e assim, é possível reconstituir-se e reformular novamente a identidade primeira. O peso do cotidiano é, de repente, tirado e os corações saltam de alegria.

A festa exprime e torna presente, de modo palpável, a finalidade da vida comunitária e, como tal, estimula a esperança e dá nova força para retomar com mais vigor a vida cotidiana. ${ }^{23}$ É um momento de celebração com música, dança, cantos, frutos e flores da terra, oração, ação de graças e também, boa comida. A refeição de festa é importante. É um dos elementos de agregação, comunhão e partilha.

\footnotetext{
${ }^{19}$ Festas e celebrações cristãs. São Paulo: Paulinas, 1981, p. 13.

${ }^{20}$ VANIER, J. Comunidade, lugar do perdão e da festa, p. 274.

${ }^{21}$ DAHLER, E. Festas e Símbolos. Aparecida: Santuário, 1999, p. 5.

${ }^{22}$ Festas e celebrações cristãs, p. 28.

${ }^{23}$ VANIER, J. Comunidade, lugar do perdão e da festa, p. 274.
} 
A refeição e a festa acabam finalmente por adquirir uma dimensão metafísica e um valor religioso. ${ }^{24}$ É assim que a história de amor entre Deus e os homens (os Patriarcas), depois entre Deus e um povo (Israel), e por fim, entre Deus e uma multidão de nações, é marcada por acontecimentos importantes que se tornaram objeto de narrativas transmitidas de geração em geração e são hoje um patrimônio para toda a humanidade. Conservadas na memória coletiva, deram origem a celebrações especiais, cuja origem é anterior ao acontecimento festejado e encontra sua raiz em tradições agrárias ancestrais: sacrifício do cordeiro da primavera para a festa da Páscoa; oferenda das primícias para a festa de Pentecostes; festa do fim das colheitas para a festa das Tendas. ${ }^{25}$

$\mathrm{O}$ termo hebraico hag é traduzido por festa e significa exatamente "formar um círculo". Assim, no contexto bíblico, a festa sempre proporciona uma reunião comunitária. A comunidade, restrita à dimensão familiar ou ampliada em nível de um povo, é o lugar da festa. A expressão festiva necessita de reunião: é a maior razão que ditou a prática das grandes peregrinações a Jerusalém no dia da Páscoa, de Pentecostes e na festa das Tendas. ${ }^{26}$

A festa bíblica, porém, não se limita jamais a evocar a lembrança de um fato passado. Ela manifesta sempre a reatualização do dom que é anterior ao fato; é uma forma nova de beneficiar-se de uma graça fundamental e vital para todo o povo de Deus. Quando um judeu celebra a Páscoa, ele tem consciência de viver aqui e agora uma libertação de fato. ${ }^{27}$

Prolongando as festas judaicas, a liturgia cristã as vivenciou desde as origens como tempos extraordinários, permitindo a renovação de uma graça inicial. "Com essas festas, o povo de Israel e depois dele a Igreja conservaram suas riquezas, forjaram sua identidade e exprimiram sua fé, sempre voltando às raízes de suas revelações e à fonte de sua vida espiritual". ${ }^{28}$ Assim, as festas da revelação judaico-cristã constituem um elemento essencial do contexto onde os personagens bíblicos evoluem e são colunas da vida litúrgica e espiritual daqueles que nos precederam na fé.

\footnotetext{
${ }^{24}$ SILVA, M. C. "A Espiritualidade da Mesa, da Refeição e da Festa. Uma realidade humana latente à Eucaristia”, Convergência 373 (2004), pp. 306-320.

${ }^{25}$ DAHLER, E. Festas e Símbolos, p. 6.

${ }^{26}$ Ibidem, p. 7.

${ }^{27}$ Ibidem, p. 6.

${ }^{28}$ Ibidem, p. 6.
} 


\section{A revelação de Deus no Êxodo}

Concebido sempre como um ser vivo, o ser humano se apresenta como um centro de relações que, de círculo em círculo, abarca todo o Universo. Embora particularizado, pessoalmente, pode estabelecer relação, comunhão com todas as coisas, com os outros seres, com o mundo e com todo o Universo, onde exerce sua liberdade e vai moldando sua história pessoal. Nesta situação terrestre, o ser humano está sujeito às coordenadas do tempo e do espaço, que comungam a todos, mas também limitam.

Não obstante esta condição, "a personalidade humana é essencialmente comunhão para fora; o simples fato de o ser humano ser corpo vivo o coloca necessariamente numa situação de abertura, contato e relação com o mundo humano e cósmico". ${ }^{29}$ Estando em busca de si mesmo, quer superar todas as alienações que o afligem como a dor, a frustração, o ódio, a morte: guarda um anseio por plenitude e por imortalidade. Quer realizar-se em todas as suas dimensões.

O pensar utópico, em busca desta realização plena, é uma das constantes em todas as culturas, desde as mais primitivas até nossos dias atuais. O pensamento mesopotâmico produziu a epopeia de Gilgamesh. A civilização egípcia foi por excelência uma civilização centrada sobre o tema da morte e da imortalidade. Os índios tupi-guarani criaram a utopia da "terra sem males" e da "pátria da imortalidade". O judaísmo bíblico criou o relato do paraíso que é uma profecia do futuro, projetada no passado. ${ }^{30} \mathrm{Um}$ dia, o homem que Deus quis e que ainda está sendo plasmado em suas mãos e pelas mãos dos próprios homens na história, nascerá, totalmente, imagem e semelhança do Criador (cf. Gn 1,26). Essa é a grande esperança do Antigo Testamento. ${ }^{31}$

A linguagem é mítica e revela o princípio-esperança que dilacera o coração humano de todas as épocas: viver na realidade concreta o anseio de plenitude, de potência total do ser e de reconciliação global com Deus, com os outros e com o mundo.

A finitude, a contingência e a dependência são características da condição humana que se lhe abrem a consciência espontânea e naturalmente para um Ser superior. ${ }^{32}$ Assim, reconhecida a existência de tal Ser, a consequência é

\footnotetext{
${ }^{29}$ BOFF, L. A nossa ressurreição na morte. Petrópolis: Vozes, 2012, p. 115-116.

${ }^{30}$ MESTERS, C. Paraíso terrestre: Saudade ou esperança? In: BOFF, L. A nossa ressurreição na morte, p. 13.

${ }^{31}$ BOFF, L. A nossa ressurreição na morte, p.13.

32 MONDIN, B. O homem: quem é ele? Elementos de Antropologia Filosófica. São Paulo: Paulus, 2008, p. 252.
} 
entrar em contato com ele em relações de oração, adoração, sacrifício, etc. É quando a dimensão religiosa assume uma estrutura regulada e ordenada.

Permanece a busca pelo sentido da vida. Permanece o anseio de encontrar respostas que libertem da angústia e do vazio existencial, cuja origem se encontra, em última análise, na vulnerabilidade e mortalidade humanas.

A tradição judaico-cristã vai responder a este anseio com a apresentação de um Deus que se manifesta de maneira bem específica e explícita ao gênero humano. ${ }^{33} \mathrm{E}$ no decorrer da história humana, neste percurso às vezes caótico e muitas vezes incompreensível, que Deus se dá a conhecer. Assim, é possível dizer que "quando Deus se revela ao ser humano, ele o faz por caminhos humanos".

A História é o campo da revelação do Deus bíblico. Os eventos muitas vezes enigmáticos são interpretados e Deus é percebido presente na história. Israel conseguiu captar nestes eventos históricos o agir de Deus. ${ }^{34}$ Foi assim que este povo concebeu a fé em seu Deus, e isto se tornou um fator determinante na formação de sua identidade na história. ${ }^{35}$

Os textos bíblicos transcendem o tempo, referindo-se à essência e ao papel do homem no mundo. Os livros da Bíblia têm como pano de fundo a história deste povo como a descrever as possibilidades concretas do desenvolvimento da existência humana. ${ }^{36}$

A história de Israel se desenvolve em uma terra específica e tem as marcas de sua localização geográfica, que muito interferirá nos acontecimentos passados aí. Tal história se desenrola à sombra do desdobramento de povos e de impérios do Antigo Oriente, mais especificamente, Mesopotâmia e Egito. ${ }^{37}$ Está sob constante impacto e dependência de episódios entre estas grandes potências da época.

No segundo milênio anterior à era cristã, o Egito passou a ser Império e foi a nação dominante do mundo. ${ }^{38}$ Nesses dias, Canaã era o nome oficial de uma província ou distrito egípcio, que abrangia o oeste da Palestina, e era habitada por diversos grupos étnicos da própria terra de Canaã e outros oriundos de fora, e que foram determinantes para a formação do futuro povo destas terras. ${ }^{39}$

\footnotetext{
${ }^{33}$ BLANK, R. Deus na História. Centros temáticos da revelação. São Paulo: Paulinas, 2005, p. 7.

${ }^{34}$ BLANK, R. Deus na História. Centros temáticos da revelação, p. 10.

${ }^{35}$ BRIGHT, J. História de Israel. São Paulo: Paulus, 2003, p. 15.

${ }^{36}$ ZILLES, U. Antropologia Teológica. São Paulo: Paulus, 2011, p. 166.

${ }^{37}$ SCHWANTES, M. História de Israel. Vol. 1: Local e origens. São Leopoldo: Oikos, 2008, p. 26.

${ }^{38}$ BRIGHT, J. História de Israel, p. 140.

${ }^{39}$ SCHWANTES, M. História de Israel. Vol. 1: Local e origens, p. 48.
} 
Os antepassados de Israel foram feitos escravos no Egito e de lá escaparam de maneira incomum. Esta opressão e a posterior libertação ocorreram no final do $13^{\circ}$ século a.C., no período do faraó Ramsés II. ${ }^{40}$ As tradições bíblicas descrevem que os hebreus foram forçados a trabalhar na construção das cidades de Pitom e Ramsés, ambas situadas no setor oriental do delta do rio Nilo, no Egito (cf. Ex 1,11).

Os textos bíblicos concordam em descrevê-los como trabalhadores forçados nas construções faraônicas. Coube-lhes construir (Ex 1,11) e fazer tijolos (Ex 1,14; 5). São oprimidos (Ex 1, 11-12; 3,7; Dt 26,6-7), tiranizados (Ex 1,13-14), escravizados (Ex 1,13-14; 2,23; 5,9; 6,5; Dt $6,21 ; 26,6)$, sobrecarregados (Ex 6,6-7), amargurados em sua vida (Ex 1,14). Realizam trabalhos forçados (Ex 1,11), são carregadores (Ex 1,11; 6,6-7); trabalham sob o comando de feitores (Ex 1,11) e de capatazes (Ex 5). Por isso, gemem e gritam. Em Ex 1,1-14, há um verdadeiro catálogo da opressão faraônica. ${ }^{41}$

A respeito destes acontecimentos, o êxodo apresenta os hebreus que, tentando escapar deste sistema, se viram encurralados entre o Mar dos Juncos e o exército egípcio e foram salvos quando um vento fez recuar as águas, permitindo que eles passassem (cf. Ex 14,21.27). Os perseguidores egípcios, surpreendidos pelas ondas que voltavam, foram todos tragados pelo mar. ${ }^{42}$

O povo se livrou da opressão do Egito sob as circunstâncias destes acontecimentos tão estupendos que ficaram impressos para sempre em sua memória. Tal libertação da escravidão ficou no centro de sua confissão de fé, como é testemunhado por poemas antigos (Ex 15,1-8) e credos (Dt 6, 20-25; $26,5-10$; Js 24, 2-13) que remontam às memórias deste período. ${ }^{43} \mathrm{~A}$ experiência desta saída com a subsequente salvação de uma situação onde tudo parecia perdido tornou-se o núcleo da concepção religiosa deste povo, em cujo centro há a convicção de que todos estes acontecimentos só foram possíveis porque Deus agiu. ${ }^{44}$

A libertação do faraó contribui, dessa forma, com a experiência histórica fundante de Israel. O Antigo Testamento atribui a este evento libertador da

\footnotetext{
${ }^{40}$ Ibidem, p. 100.

${ }^{41}$ SCHWANTES, M. História de Israel. Vol. 1: Local e origens, p. 89.

${ }^{42}$ BRIGHT, J. História de Israel, p. 157.

${ }^{43}$ Ibidem, p. 155.

${ }^{44}$ BLANK, R. J. Deus na História. Centros temáticos da revelação, p. 79.
} 
saída do Egito um papel fundamental para a existência deste povo, o povo de Deus. Na síntese da fé israelita, cabe ao êxodo o lugar privilegiado. Na libertação nasceu o povo. ${ }^{45} \mathrm{O}$ grupo que saiu do Egito, escapando de um sistema opressor, não ficou despercebido. A mensagem de que um grupo de escravos teria escapado do poder do faraó espalhou-se. Acontecera algo extraordinário.

Assim, muitos grupos se unem ao clã que havia saído do Egito em um processo de fusão de muitos grupos e de etnias diferentes, resultando no que os textos bíblicos chamam de "povo de Israel". ${ }^{46} \mathrm{E}$, na sequência, adotam o Deus daqueles que tinham conseguido escapar do sistema do faraó. Espalha-se o conhecimento daquele Deus que agiu contra os opressores, em favor daqueles que eram oprimidos; seu agir foi em favor dos desprivilegiados e contra os que detinham o poder. Junto com tal conhecimento começa a se formar uma consciência de solidariedade, uma consciência étnica cuja base é a veneração deste mesmo Deus responsável pela saída do Egito.

Pode-se dizer que a experiência histórica feita com Deus, espalha o conhecimento deste Deus e de sua ação libertadora: "um Deus que transcende as condições possíveis e irrompe na história, abrindo futuro a situações sem futuro, abrindo possibilidades de vida para quem foi roubado destas condições. Portanto, o Deus dos hebreus torna-se central, nas tradições vétero-testamentárias, por seu próprio agir inusitado". ${ }^{47}$

\section{A aliança}

Sob a condução de Moisés, o líder na fuga do Egito, o povo dos escravos hebreus $($ Ex 12,38) vai peregrinar pelo deserto, na direção do monte Sinai (ou Horeb, como também é chamado), localizado, provavelmente, a sudeste do Mar Morto. ${ }^{48}$ Salvos dos opressores egípcios, iniciam um longo caminho pelo deserto rumo à Terra Prometida (Ex 15,22-Nm 21,20). Este caminhar no deserto é tão significativo para a religião do futuro povo de Israel que estará presente em setenta e três capítulos de quatro livros bíblicos: Êxodo, Levítico, Números e Deuteronômio.

Os autores do Pentateuco, os primeiros cinco livros da Bíblia, onde tais livros estão inseridos, não têm pressa em narrar as variadas experiências rela-

\footnotetext{
${ }^{45}$ SCHWANTES, M. História de Israel. Vol. 1: Local e origens, p. 84.

${ }^{46}$ BLANK, R. J. Deus na História. Centros temáticos da revelação, p. 85.

${ }^{47}$ SCHWANTES, M. História de Israel. Vol. 1: Local e origens, p. 104.

${ }^{48}$ Ibidem, p. 112.
} 
cionadas a este período. ${ }^{49}$ Nesta narrativa, através da mediação de Moisés, é dada ao povo de Israel no monte Sinai/Horeb por Deus, a Torá ${ }^{50}$, um conjunto de disposições legais. Após a chegada do povo ao monte de Deus, o Sinai, acontece uma espécie de prelúdio, no qual é fundada uma organização jurídica (Ex 18). Segue-se uma teofania (Ex 19), na qual se comunica o Decálogo ${ }^{51}$ (Ex 20). Moisés receberá, ainda, um bloco de leis, o Código da Aliança, e uma grande quantidade de outras orientações de Deus, comunicada ao povo. É no monte de Deus que se realiza a vinculação definitiva do povo ao Senhor. ${ }^{52} \mathrm{~A}$ Torá vai tratar da comunicação da vontade do único Deus e criador de todas as pessoas a seu povo eleito, Israel. ${ }^{53}$

Os quarenta anos de caminhada no deserto podem ser interpretados como um processo educativo, onde Deus quis chamar Israel para si, permitindo que sentisse dependência e experimentasse sua providência. ${ }^{54}$ É Ele quem garante a sobrevivência todo o tempo: transforma águas amargas em águas doces (Ex 15,22-27), envia alimento (Ex 16) - maná e codornizes -, faz brotar água da rocha (Ex 17, 6) e ouve clamores e pedidos do povo.

Há um difícil caminho neste rumo à liberdade. Não se inverte facilmente uma situação de miséria e opressão como aquela em que viviam os hebreus

${ }^{49}$ GRENZER, M. O projeto do êxodo. São Paulo: Paulinas, 2007, p. 67.

${ }^{50}$ CRÜSEMAN, F. A Torá. Teologia e história social da lei do Antigo Testamento. Petrópolis: Vozes, 2002, p. 19. A palavra torah designa, em linguagem coloquial da época do Antigo Testamento, o ensinamento da mãe $(\operatorname{Pr} 1,8 ; 6,20)$ e do pai $(\operatorname{Pr} 4,1 \mathrm{~s})$ para introduzir seus filhos nos caminhos da vida e adverti-los diante das ciladas da morte. A palavra abrange informação e orientação, instrução e estabelecimento de normas, e, com isso, promessa e desafio, também. Expressa igualmente o mandamento e a história da instrução da qual emerge. A partir disso, o conceito Torá torna-se um termo técnico para a instrução dos sacerdotes e também a palavra dos mestres da sabedoria ou do profeta. Por fim, Torá transforma-se no conceito mais importante da vontade de Deus, expressa tanto em narrações quanto em leis. Posteriormente, o conceito evolui para designar todo o Pentateuco, designando a Lei de Deus, sua palavra profética para todos os povos.

${ }^{51}$ SKA, J. L. Introdução à leitura do Pentateuco. Chaves para a interpretação dos cinco primeiros livros da Bíblia. Bíblica Loyola 37. São Paulo: Loyola, 2003, p. 63. O decálogo constitui o texto fundamental de toda a lei do Antigo Testamento. É o único texto que Deus transmite ao povo, diretamente, sem a mediação de Moisés (Ex 20,1; Dt 5,4). Além do mais, se reafirma várias vezes, que o próprio Deus o escreveu em duas tábuas de pedra (Ex 24,12; 31,$18 ; 32,15 ;$ Dt 5,22).

${ }^{52}$ DONNER, H. História de Israel e dos povos vizinhos. Volume 1: Dos primórdios até a formação do Estado. São Leopoldo: Sinodal, 1997, p. 116.

${ }^{53}$ CRÜSEMAN, F. A Torá, p. 14. A Torá expressa orientações que são dirigidas a todas as pessoas.

${ }^{54}$ GRENZER, M. O projeto do êxodo, p. 141. 
sob o domínio do faraó egípcio. Todavia, a recuperação da dignidade dos oprimidos é vista como vontade do Deus de Israel. É no deserto, lugar de muitos sofrimentos e perigos, que o povo libertado poderá experimentar Deus como aquele que cura. ${ }^{55}$

Após este longo período pelo deserto, Israel toma posse da terra e nela começa sua vida como povo, trazendo consigo uma religião sem paralelo no mundo antigo. A história de Israel leva em conta sua religião, porque foi ela quem o singularizou, separando-o de todos os povos que o cercavam e tornando-o um fenômeno especial.

É quando Israel vai conceber sua religião característica e se tornar um povo. É, também, quando Deus será conhecido como "o Deus do Sinai" conforme alguns dos poemas bíblicos mais antigos afirmam: Jz 5,4ss; S1 68,8 s; e Dt $33,2 .{ }^{56}$ Assim, este povo passa a ser uma comunidade e a possuir uma identidade própria com seu Deus, que o tinha libertado para que pudesse chegar à terra que ele, o Senhor, havia prometido aos antepassados. ${ }^{57}$

Pode-se afirmar, portanto, que "no início da história de Israel, como o Antigo Testamento a narra, não estava uma obra humana nem um acontecimento natural, mas sim a ação salvadora de Deus: "Mas eu, o Senhor, sou teu Deus desde o Egito; um deus além de mim tu não conheces, e outro salvador não existe"! (Os 13,4)"..$^{58}$

A religião de Israel é centrada nessa consciência do relacionamento entre Deus e o povo. Desenvolve-se a crença de que o Senhor tinha escolhido Israel como objeto de seu especial favor e que Israel, por sua vez, tinha se comprometido com Ele como seu povo. "Foi simplesmente aqui que a noção de governo de Deus sobre seu povo, o Reino de Deus, teve seu início". 59

É a partir desta crença que se formou a primitiva organização social e jurídica israelita bem como suas tradições e instituições sagradas. Os símbolos do culto primitivo eram símbolos desse reinado, como por exemplo, a Arca, que era o Trono de Deus (cf. Nm 10,35ss).

A relação de Israel com seu Deus depende da aceitação da soberania de Deus. À noção que Israel tinha de si mesmo como povo escolhido era acres-

\footnotetext{
${ }^{55}$ Ibidem, p. 69.

${ }^{56}$ BRIGHT, J. História de Israel, p. 161.

${ }^{57}$ Ibidem, p. 178.

${ }^{58}$ DONNER, H. História de Israel e dos povos vizinhos. Volume 1: Dos primórdios até a formação do Estado, p. 112.

${ }^{59}$ BRIGHT, J. História de Israel, p. 194.
} 
centada uma nota moral que não deveria ser esquecida: Israel não era um povo superior, favorecido porque merecesse favores, mas um povo indefeso, que havia recebido uma graça imerecida. Deus o tinha escolhido quando ele mais necessitava e o escolheu por um ato moral livre.

A sociedade entre eles se fundamentava em uma Aliança, que exigia obediência para ser mantida. As cláusulas, primariamente, eram que Israel aceitasse o domínio de seu Deus, não tivesse contato algum com nenhum outro deus e obedecesse à sua Lei. ${ }^{60}$ Tal Aliança, porém, permanece sempre válida, mesmo em caso de infidelidade do povo eleito. ${ }^{61}$ É dessa forma que os conjuntos de leis do Antigo Testamento devem ser entendidos adequadamente. É no conjunto da Aliança fundamental de Deus que elas têm importância. É somente na Aliança que a Torá tem o seu lugar. ${ }^{62}$

A libertação do povo hebreu da escravidão egípcia, a permanência no deserto e a chegada à Terra da Promessa podem ser lidas sob a ótica de um projeto único de êxodo, cuja perspectiva ética e teológica é o fundamento da fé bíblica. Neste projeto, o Deus de Israel revela suas características identificadoras: atento ao povo oprimido o conduz para fora da sociedade que o oprime, dá-lhes seu ensino e os leva a uma terra "boa", afim de que libertados construíssem uma sociedade alternativa, que garantisse de forma mais ampla a liberdade a todos os seus membros. ${ }^{63}$

Assim, desde o início da sua história com a saída do Egito, Israel faz a experiência do Deus libertador e salvador: tal é o testemunho da Bíblia, que descreve como tudo ocorreu. A passagem milagrosa do mar se torna um dos temas principais do louvor a Deus: a saída do Egito, juntamente com a entrada na Terra Prometida (Ex 15,17), torna-se a afirmação principal da confissão de fé: a intervenção do Senhor nesse evento salvífico é fundamental para Israel. ${ }^{64}$

Toda a tradição posterior vai considerar e celebrar o êxodo do Egito como a hora do nascimento do povo de Israel, como o grande acontecimento salvífico com o qual o Senhor inaugurou a condução do seu povo eleito. ${ }^{65}$

\footnotetext{
${ }^{60}$ BRIGHT, J. História de Israel, p. 195.

${ }^{61}$ CRÜSEMAN, F. A Torá, p. 205.

${ }^{62}$ Ibidem, p. 14.

${ }^{63}$ GRENZER, M. O projeto do êxodo, p. 13.

${ }^{64}$ PONTIFÍCIA COMISSÃO BÍBLICA. O povo judeu e suas Sagradas Escrituras na Bíblica cristã. São Paulo: Paulinas, 2002, p. 83.

${ }^{65}$ DONNER, H. História de Israel e dos povos vizinhos. Volume 1: Dos primórdios até a formação do Estado, p. 125.
} 


\section{A ceia pascal dos judeus}

A páscoa judaica (Pesah) é uma das três festas de peregrinação dos judeus. ${ }^{66}$ É a principal delas e tem raízes antigas e complexas, que devem ser buscadas em duas festas relacionadas com a vida e a natureza. A primeira é a festa da imolação dos cordeiros na primavera, um rito próprio dos pastores nômades, que oferecem a Deus as primícias de seus rebanhos; durava uma só noite de luar. A outra é a festa dos pães ázimos, um rito mais próprio dos povos agrícolas, sedentários, que também oferecem a Deus os primeiros frutos de suas colheitas (cf. Ex 12, 15-20) e durava vários dias. ${ }^{67} \mathrm{O}$ povo de Israel, conservando as características destes ritos, acrescentou o sentido da libertação e saída do Egito e da Aliança feita com o Senhor no Monte Sinai. O que poderia ser apenas uma festa ligada à natureza converteu-se em um memorial da salvação operada por Deus em favor de seu povo. Dessa forma, a páscoa se enriqueceu em seu conteúdo.

É importante apontar que o memorial para o judeu possui duas dimensões: uma descendente, na qual Deus se lembra do seu povo, de sua aliança com ele e de suas próprias promessas; e outra ascendente, onde o ser humano, por sua vez, lembra a ação de Deus e o bendiz diante dos demais. O memorial é uma das atitudes mais características para a cultura religiosa israelita. De fato, todo memorial tem para os judeus sentidos profundos:

- Olhar o passado, projetando-o para o futuro: o acontecimento histórico e o futuro se encontram no "hoje" da celebração (isto se dá, particularmente, na Páscoa);

- O presente é continuidade com o passado e antecipação do futuro. Entra-se na dinâmica do memorial, sentindo-se contemporâneo dos fatos passados e destinatário dos bens futuros.

- O memorial ritual, cúltico, perpetua a presença do acontecimento histórico. $^{68}$

\footnotetext{
${ }^{66}$ As outras duas são a festa das Semanas (Shavuot) e a das Tendas (Sukkot). Cf. GONZALEZ-QUEVEDO, L. "A Última Ceia no seu contexto judaico", Itaici. Revista de Espiritualidade Inaciana 61 (2005), pp. 37-53.

${ }^{67}$ ALDAZÁBAL, J. A Eucaristia, p. 46.

${ }^{68}$ ALDAZÁBAL, J. A Eucaristia, p. 44.
} 
A palavra 'páscoa' vem do hebraico pesah, que parece significar "saltar, passar por cima". ${ }^{69}$ Talvez em alusão a algum salto ritual e festivo dos povos mais primitivos, este significado primeiro deu lugar à referência do Senhor que "passou de largo" pelas portas dos israelitas no último sinal dado aos egípcios (a décima praga ${ }^{70} \mathrm{e}$, mais tarde passou a referir-se à passagem do mar e à travessia da escravidão à liberdade, seguindo preceito do próprio Deus. ${ }^{71} \mathrm{O}$ desenrolar da ceia pascal se dividia em quatro partes: ${ }^{72}$

- O qiddush (santificação): o pai de família pronuncia a primeira bênção. Todos os presentes bebem seu cálice. Comem verduras molhando-as num molho especial. ${ }^{73} \mathrm{O}$ pai parte o pão ázimo ${ }^{74}$ em duas porções: uma é escondida para o final da ceia e a outra vai sendo dada a todos.

- A haggadah (relato, homilia): a partir de perguntas das crianças e de respostas do pai, é contada a história da ida ao Egito, da escravidão e da libertação obtida por meio de Moisés. Há uma atualização da história da salvação, um memorial. Depois, todos bebem o segundo cálice, lavam as mãos e então participam da ceia pascal, caracterizada pelo cordeiro pascal. ${ }^{75}$

- A birkat há-mazon (ação de graças após a refeição): serve-se o terceiro cálice de vinho, o pai pronuncia a bênção (berakah) mais solene da ceia e todos bebem.

- O hallel (salmos de louvor): sobre o quarto cálice, se dizem os Salmos 114 a 117, além do Salmo 135 junto com outras bênçãos; termina-se com "no próximo ano em Jerusalém".

\footnotetext{
${ }^{69}$ ALDAZÁBAL, J. A Eucaristia, p. 46.

${ }^{70}$ As dez pragas do Egito são as pragas que Deus enviou pelas mãos de Moisés sobre o Faraó do Egito e seu povo, narradas no livro bíblico do Êxodo, capítulos 7 a 12. As pragas foram enviadas para que Israel fosse libertado da terra do Egito e se reconhecesse a unicidade de Deus. A décima praga tem a ver com a morte de todo primogênito. O sangue do cordeiro aspergido no batente das portas das casas dos hebreus os livrou de serem atingidos pelo castigo divino.

${ }^{71}$ Cf. Ex 12,14 - "Conservareis a memória daquele dia, celebrando-o com uma festa em honra do Senhor: fareis isto de geração em geração, pois é uma instituição perpétua".

${ }^{72}$ ALDAZÁBAL, J. A Eucaristia, p. 47-48. À época de Jesus cf. reconstituição feita a partir da Mishná, uma das principais obras do judaísmo rabínico e a primeira grande redação escrita da tradição oral judaica, chamada Torá oral. É redigida por volta do ano 200 d.C.

${ }^{73}$ As ervas amargas lembram a amargura da servidão no Egito.

${ }^{74} \mathrm{O}$ pão não fermentado é um sinal da pressa com a qual foi necessário fugir do país do faraó.

${ }^{75}$ Os cordeiros eram sacrificados no Templo a partir do meio-dia do dia 14 de Nisã, e depois, assados e comidos nas casas, inaugurando assim a grande festa. Caracterizada em Jerusalém, antes da queda e ruína do ano 70.
} 
A ceia da páscoa é para os judeus sinal e celebração da salvação operada por Deus; ela se converteu no ponto máximo de referência para a teologia e espiritualidade judaicas, apresentando um resumo da fé e do culto judeu.

É dentro deste contexto pascal judaico que se apresenta a ceia dos discípulos com Jesus e se pode compreender a pergunta deles ao Mestre: "Onde queres que façamos os preparativos para comeres a Páscoa?" (Mc 14, 12). As palavras pronunciadas por Jesus, seus gestos e ações nesta última ocasião foram transmitidas em quatro versões,${ }^{76}$ evidenciando sua importância. Tal sentido está contido no ritual da Páscoa, conhecido pelos discípulos. Jesus acrescenta às orações do começo e do fim da ceia palavras de explicação, comparando o pão partido ao seu corpo e o vinho ao seu sangue.

Os grandes temas pascais podem ser assim apresentados: ${ }^{77}$

- uma celebração comunitária, familiar, na consciência de ser o povo eleito de Deus;

- uma celebração que renova a cada ano a Aliança do povo com Deus, solenemente, selada no passado no monte Sinai e, que agora, se atualiza (cf. Ex 13,3-10);

- a celebração é a salvação pascal: a "passagem" da morte (escravidão, juízo e ira de Deus) à vida (alegria, liberdade, amizade com Deus, terra prometida);

- o cordeiro pascal é o elemento característico como um símbolo: primeiro como oferenda primaveril de cordeiros, depois como lembrança do cordeiro sacrificado na saída do Egito, ${ }^{78}$

- o pão ázimo, sem levedura, utilizado em toda a semana da páscoa, como recordação simbólica da aflição, escravidão e pressa na saída do Egito (cf. Ex 12,39);

- o vinho simbolizando os dons da Terra Prometida ${ }^{79}$ (cachos de uva) é também símbolo da alegria e da espera messiânica.

\footnotetext{
${ }^{76}$ As quatro versões se encontram nos três evangelhos sinóticos e em Paulo (1Cor).

${ }^{77}$ ALDAZÁBAL, J. A Eucaristia, p. 49.

${ }^{78} \mathrm{Cf}$. Ex 12,46 - a lei relativa à Páscoa dada pelo próprio Deus.

${ }^{79}$ Terra Prometida é o termo utilizado para descrever a terra prometida ou dada por Deus aos patriarcas dos hebreus: Abraão, Isaac e Jacó. A promessa foi feita primeiramente a Abraão e, então, renovada ao seu filho Isaac e depois ao filho deste, Jacó. A promessa que é a base do termo está contida em vários versículos do Gênesis, na Torá. Em Gn 12,1 é dito: "Então o Senhor disse a Abrão: "Saia da tua terra, do meio dos seus parentes e da casa de seu pai, e vá para a terra que eu lhe mostrarei"” e em Gn 12,7: "O Senhor apareceu a Abrão e disse: "À sua descendência darei esta terra"'”.
} 
A ceia pascal é vivida como convergência do passado, do presente $e$ do futuro: ${ }^{80} \mathrm{o}$ fato histórico é lembrado e proclamado com gratidão, mas há também um olhar esperançoso voltado para o futuro messiânico ${ }^{81}$, na convicção de que hoje mesmo, quando se está celebrando a páscoa, se atualiza tal salvação passada e futura. "O memorial não é algo meramente pedagógico, mas sacramentalmente eficaz: a salvação de Deus chega "a nós"." 82

Uma prova da importância da Páscoa para a religiosidade judaica é o Poema das quatro noites do Targum ${ }^{83}$, que pode ser lido como chave de interpretação da história da salvação. Segundo a tradição judaica, há na vida do mundo quatro noites diferentes de todas as outras:

A primeira é a noite da Criação, aquela noite em que Deus criou o céu, a terra, o mar, os animais, e as flores e o sol... e o homem e a mulher. Deus ama esta vida que Ele criou e se envolve com ela.

A segunda noite é a noite da promessa de Deus a Abraão. Foi uma noite de verão, toda cheia de estrelas, quando Deus prometeu a nosso pai na fé uma descendência tão numerosa como as estrelas do céu e as areias do mar. Deus lhe prometeu, também, a terra em que tinha caminhado, de acampamento em acampamento, vadeando rios e atravessando desertos. Em Abraão, Deus prometeu aos seus seguidores uma Aliança eterna.

A terceira noite é a noite do êxodo, da travessia do Mar Vermelho, quando o povo hebreu saboreou a liberdade. É a noite em que nasce a esperança de uma vida nova, na Terra Prometida; a noite em que Deus diz a seu povo: "caminha, não tenhas medo, estou contigo!" É uma noite alegre, em que os judeus comem maçãs, entre outros manjares e leem o Cântico dos Cânticos.

Finalmente, a quarta noite é a noite em que Deus enviará o seu Messias, noite aberta, na qual acontecerá a salvação definitiva. A religião judaica

\footnotetext{
${ }^{80}$ ALDAZÁBAL, J. A Eucaristia, p. 50.

${ }^{81}$ Os judeus acreditam que o "Messias", que é uma pessoa particularmente enviada por Deus, um dia virá ao mundo. A chegada do Messias vai trazer consigo uma era de paz.

${ }^{82}$ ALDAZÁBAL, J. A Eucaristia, p. 50.

${ }^{83}$ Targum é a designação de versões aramaicas da Escritura Hebraica. Após o retorno do exílio na Babilônia, século VI a.C., o aramaico ganhou ascendência sobre o hebraico como linguagem coloquial. Como a maioria da população deixou de estar familiarizada com a língua sagrada tornou-se necessário fornecer traduções para o melhor entendimento das passagens bíblicas lidas em hebraico nos serviços litúrgicos. Assim, para atender a essa necessidade, tornou-se habitual adicionar à leitura das Escrituras, uma tradução oral - um Targum. No caso, o Targum Palestinense.
} 
volta-se assim para o futuro, em atitude de esperança, nunca realizada plenamente nesta vida. Na festa familiar da Páscoa, as portas devem estar abertas, em atitude de amizade, porque nesta noite, não só o passado, mas também o futuro se torna presente. ${ }^{84}$

Todas essas etapas são celebradas na ceia pascal dos judeus. O ritual adquire, assim, uma grande importância, introduzindo seus participantes na dinâmica da salvação de Deus.

Ao finalizar, vale apontar que na Eucaristia tal caráter - a Salvação explicita um autêntico "projeto teológico", o qual visa assegurar a continuidade da ação salvífica de Deus no meio do seu povo. Desta forma pode-se afirmar que em Jesus Cristo, Deus estabelece a Nova Aliança, não apenas com Israel, mas com toda a humanidade. Neste sentido, a última ceia com os Doze pode representar o "novo" Israel, o novo povo, que teria reconhecido na maneira de Jesus partir o pão e dar de beber do cálice a renovação do projeto de libertação do êxodo - tão central para a espiritualidade judaica - bem como a renovação definitiva e plena da Aliança. ${ }^{85}$

\section{Conclusão}

A grandeza e a originalidade de Jesus podem ser mais bem compreendidas com e dentro do judaísmo. A liturgia é o terreno privilegiado deste conhecimento, desta escuta. É nela, mais do que em qualquer outra expressão da tradição judaica, que estão reunidos e resumidos os tesouros bíblicos e espirituais. Ela é considerada como o "contexto" ou o "lugar de origem" da

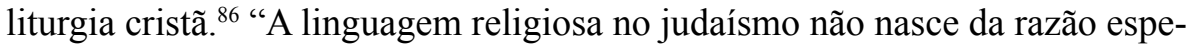
culativa, mas da paixão e da força de uma experiência de vida marcada pela presença e pela palavra de Deus". ${ }^{87}$ Voltar a este espaço no qual Israel viveu sua experiência de povo de Deus, entrar neste universo, no qual os cristãos também estão ligados é voltar às origens da liturgia cristã e reconhecer que suas bases foram emprestadas da tradição judaica.

\footnotetext{
${ }^{84}$ AS QUATRO noites. Itaici. Revista de Espiritualidade Inaciana 61 (2005), p. 54.

${ }^{85}$ BUSTAMANTE, J. M. A. Dimensões sociais da ceia pascal celebrada por Jesus. Um estudo literário e histórico-teológico de Mc 14, 22-25. 2009, p. 38.

${ }^{86}$ DI SANTE, C. Liturgia Judaica. Fontes, estrutura, orações e festas, p. 16-17.

${ }^{87}$ DI SANTE, C. Liturgia Judaica. Fontes, estrutura, orações e festas, p. 15.
} 


\section{Referências Bibliográficas}

ALDAZÁBAL, J. A Eucaristia. Petrópolis: Vozes, 2002.

AS QUATRO noites. Itaici. Revista de Espiritualidade Inaciana 61 (2005), p. 54.

BENTO XVI. Sacramentum Caritatis. Exortação Apostólica Pós-Sinodal. São Paulo: Paulinas, 2007.

BUStAMANTE, J. M. A. Dimensões sociais da ceia pascal celebrada por Jesus. Um estudo literário e histórico-teológico de Mc 14, 22-25, 2009, 123p. Dissertação (Mestrado em Teologia Sistemática). Pontifícia Faculdade de Teologia Nossa Senhora da Assunção. São Paulo.

BLANK, R. Deus na História. Centros temáticos da revelação. São Paulo: Paulinas, 2005.

BOFF, L. A nossa ressurreição na morte. Petrópolis: Vozes, 2012.

BRIGTH, J. História de Israel. São Paulo: Paulus, 2003.

BROUARD, M. Eucharistia. Enciclopédia da Eucaristia. São Paulo: Paulus, 2007.

CRÜSEMANN, F. A Torá. Teologia e história social da lei do Antigo Testamento. Petrópolis: Vozes, 2002.

DAHLER, E. Festas e Símbolos. Aparecida: Santuário, 1999.

DI SANTE, C. Liturgia Judaica. Fontes, estrutura, orações e festas. São Paulo: Paulus, 2004.

DONNER, H. História de Israel e dos povos vizinhos. Vol 1: Dos primórdios até a formação do Estado. São Leopoldo: Sinodal, 1997.

Festas e celebrações cristãs. São Paulo: Paulinas, 1981.

GONZALEZ-QUEVEDO, L. “A Última Ceia no seu contexto judaico”, Itaici. Revista de Espiritualidade Inaciana 61 (2005), pp. 37-53.

GRENZER, M. O projeto do êxodo. São Paulo: Paulinas, 2007.

JEREMIAS, J. Isto é o meu corpo. São Paulo: Paulinas, 1972.

LÉON-DUFOUR, X. O Pão da Vida. Um estudo teológico sobre a Eucaristia. Petrópolis: Vozes, 2010. 
MONDIN, B. O homem, quem é ele?. Elementos de Antropologia Filosófica. São Paulo: Paulus, 2008.

PONTIFÍCIA COMISSÃO BÍBLICA. O povo judeu e suas Sagradas Escrituras na Bíblica cristã. São Paulo: Paulinas, 2002.

SCHWANTES, M. História de Israel: local e origens. vol. 1. São Leopoldo: Oikos, 2008.

SILVA, M. C. A Espiritualidade da Mesa, da Refeição e da Festa. Uma realidade humana latente à Eucaristia. Convergência 373 (2004), pp. 306-320.

SKA, J. L. Introdução à leitura do Pentateuco. Chaves para a interpretação dos cinco primeiros livros da Bíblia. Bíblica Loyola 37. São Paulo: Loyola, 2003.

VANIER, J. Comunidade, lugar do perdão e da festa. São Paulo: Paulinas, 2006.

ZILLES, U. Antropologia Teológica. São Paulo: Paulus, 2011.

Boris Agustín Nef Ulloa

Doutor em Teologia Bíblica pela Pontificia Università Gregoriana Docente no Programa de Estudos Pós-Graduados em Teologia da Pontifícia Universidade Católica de São Paulo São Paulo / SP - Brasil E-mail: baulloa@pucsp.br

\section{Regina Ribeiro Graciani}

Mestranda em Teologia pela Pontifícia Universidade Católica de São Paulo Graduada em Teologia pela Pontifícia Universidade Católica de São Paulo e em Nutrição pela Universidade de São Paulo São Paulo / SP - Brasil E-mail: reginagraciani@uol.com.br

Recebido em: 04/08/14 Aprovado em: 27/10/14 